\title{
A new look at the Butic Canal, Egypt
}

\author{
Robert Schiestl \\ Institute of Ancient History, Ludwig-Maximilians-University Munich, 80539 Munich, Germany
}

Correspondence: Robert Schiestl (robert.schiestl@lmu.de)

Relevant dates: $\quad$ Received: 24 August 2020 - Accepted: 2 November 2020 - Published: 26 January 2021

How to cite:

Schiestl, R.: A new look at the Butic Canal, Egypt, E\&G Quaternary Sci. J., 70, 29-38, https://doi.org/10.5194/egqsj-70-29-2021, 2021.

Abstract:

The Butic Canal - a Roman period transversal route across the northern Nile Delta - was the longest artificial watercourse in the Nile Delta, yet it remains very poorly understood. To date, the canal has not yet been verified by archeological excavations. The route of the eastern section of the canal has been indirectly identified based on a linear elevated feature most likely representing earth from the excavation of the canal. This study combines the analysis of historical sources and remote sensing data, such as satellite imagery and the TanDEM-X digital elevation model, in order to discuss its date of construction, route, and functions. Based on the data of the digital elevation model, new constructional features are visible in the eastern delta providing the first detailed route of a Roman-era artificial watercourse in Egypt. It is suggested that the canal's construction is placed in the context of imperial investments in the infrastructure of the eastern part of the Roman empire.

Kurzfassung: Der Butische Kanal war eine römerzeitliche Querverbindung durch das nördliche Nildelta. Obwohl er die längste künstliche Wasserstraße des Deltas darstellt, ist unsere Kenntnislage über diesen Kanal sehr gering. Bis heute ist der Kanal nicht durch archäologische Ausgrabungen verifiziert. Der Verlauf eines Abschnitts des Kanals im östlichen Nildelta wurde indirekt durch eine lineare Struktur identifiziert, die höchstwahrscheinlich den Aushub des Kanals repräsentiert. Dieser Artikel kombiniert die Analyse historischer Quellen und Fernerkundungsdaten, wie Satellitenbilder und das TanDEM$X$ Digitale Höhemodell, um die Datierung, die Route und die Funktionen des Kanals zu diskutieren. Auf der Grundlage der Daten des Digitalen Höhenmodells sind im östlichen Delta bestimmte bauliche Merkmale des Kanals erstmals genauer erkennbar. Dadurch kann die erste detaillierte Route eines Abschnittes einer römerzeitlichen künstlichen Wasserstraße in Ägypten rekonstruiert werden. Es wird vorgeschlagen, die Errichtung des Kanals im Zusammenhang mit imperialen Infrastrukturprojekten in der Osthälfte des römischen Reiches zu verstehen.

\section{Introduction}

The Boutikos potamos, the Butic Canal, is named and described only in one ancient source, a 2nd century CE geographic treatise written in Greek by Ptolemy (Klaudios Ptolemaios, 4, 5, 44; Stückelberger and Graßhoff, 2006). The term potamos can refer to both natural and artificial watercourses
(Bonneau, 1993). Here it is clearly an artificial watercourse spanning the Egyptian Nile Delta from west to east with a reconstructed length of about 185 to $200 \mathrm{~km}$. Thus, it constitutes the longest man-made ancient watercourse in the delta, distinctly longer than the other major ancient delta canal which connected the Nile to the Red Sea (Cooper, 2009). Despite its size and unique route, very little is known about this 
canal. Recent discussions of the canal have addressed it in a wider delta perspective, looking at it in the context of transdelta networks (Redon, 2018) but also including the course in a regional setting in the eastern delta (Blouin, 2014). To date, however, it has never been the topic of a specialized study. This holds true for the field of Egyptology, but also within the wider scope of ancient water technology (Wikander, 2000; Grewe, 2009) and Roman imperial construction, this watercourse finds no mention. While the Butic Canal does appear on maps of the Nile Delta (Ball, 1942; Bietak, 1975; Talbert, 2000; Wittke et al., 2007), the course is largely conjectural, attempting to place Ptolemy's description of the canal in the landscape. Its precise course, its date of construction, its period of activity, and its purpose(s) remain in discussion (Ball, 1942; Bietak, 1975; Yoyotte, 1987; Blouin, 2014; Redon, 2018) as does the question of its influence on the traffic, development, and economy of the delta. The background to this study is a survey which was conducted in the northwestern delta in the region of Buto (Tell el-Fara'in; Schiestl, 2012). For the surveyed area, see the yellow rectangle in Fig. 1. Traditionally, reconstructions of the course of the Butic Canal show it passing close to Buto and crossing the area surveyed. As the survey pursued, inter alia, a landscape archeological angle, the ancient land- and waterscapes were investigated using historic maps, satellite images, auger core drillings, and a digital elevation model (DEM). While this has resulted in much new information on the ancient water courses of the region (Ginau et al., 2019), no features were discerned which suggest themselves as a regional segment of the Butic Canal. Empirical evidence for this canal in the western delta remains elusive. In contrast, in the eastern delta, a linear elevated feature, still in parts extant between Mendes/Thmuis and Tanis (red rectangle on Figs. 1, 2a-c), has long been considered as evidence of the remains of the excavated earth of the Butic Canal. New data from the TanDEM-X digital elevation model provide new details of this feature which will be discussed in the following Sect. 4 in the context of the reconstruction of the route. This will be preceded by a discussion of the textual sources for the canal (Sect. 2) and the chronology (Sect. 3) and will be followed by an analysis of the functions of the canal (Sect. 5) and a summary of the main results (Sect. 6). Methodologically, this investigation combines ancient historical textual sources, archeological sources, and remote sensing information.

\section{Textual evidence}

There are two main textual sources describing a Roman period (30 BCE-7th century $\mathrm{CE}$ ) transversal delta canal which are frequently considered as referring to the same system. The earlier one is an indirect reference in Flavius Josephus' History of the Jewish War (Jos. BI, IV, 11, 5). In 70 CE, during the reign of Vespasian, his son Titus moved troops from Alexandria to Judea in order to quell the Jewish uprising. Josephus describes how this was done: marching from Alexandria east to Nikopolis, the troops boarded ships there. They then sailed to the Mendesian nome as far as Thmuis. Here the army disembarked and continued on foot, the assumption being that the canal had ended at this point. No name for this west-east canal is, however, given, and geographic details for the course are lacking. The first leg of the journey was undertaken on a canal linking Nikopolis to Schedia on the Canopic branch of the Nile. While this canal's course has also not yet been archeologically verified, textual evidence exists which also provides a name, Agathos Daimon. In year 7 of Titus' reign (80/81), 14 stelae were erected along the Agathos Daimon canal documenting its repair (Zimmermann, 2003; Scheuble, 2009; Jördens, 2009). The name Agathos Daimon was later transferred to the Canopic branch, as evidenced by Ptolemy (5, 42-43). Further names, such as the Sebastos canal and the Philagrian canal, refer to the same or other canals linking the Canopic branch and Alexandria; they represent potential alternative routes taken by Titus and his soldiers (Jördens, 2009; Hairy and Senounne, 2011). Whether the canal used by Titus and his soldiers is an early, partial version of the Butic Canal (Ball, 1942; Bietak, 1975) or an entirely separate construction (Redon, 2018) is a matter of debate. The second source is the Geography by Ptolemy from the mid-2nd century CE $(4,5,44$; Stückelberger and Graßhoff, 2006). It is only here that the canal is actually named Boutikos potamos, and its course spans the entire width of the delta, running "parallel to the coast of the Mediterranean" and connecting the Canopic (= Agathodaemon) branch with the Thermuthiakos, Athribikos, Busiritikos, and Bubastikos branches.

\section{Chronology}

The two halves of the trans-delta canal, the western half from the Agathodaemon/Canopic branch to Thmuis and the eastern half from Thmuis to Pelusium, have individual biographies and are best analyzed separately. While the eastern half was not functional in Vespasian's time, there are textual and archeological arguments for the existence of earlier, preRoman versions (Blouin, 2014; Redon, 2018). A biographical inscription on the backpillar of a statue of the Ptolemaic official Pamerih from Tanis (Cairo, CG 687) from the 2nd century BCE references a journey from the region of Busiris in the central delta to Tanis in the eastern delta which is assumed to have been conducted on a canal (Zivie-Coche, 2004). Bietak (1975) proposed that the Butic Canal on this stretch replaced an earlier land route. A series of important towns in the eastern delta are aligned along roughly the same latitude, ca. $30^{\circ} 57^{\prime}$, which suggests they were linked by a road or an earlier canal. The foundations of these towns range from the Predynastic Period at Mendes (late 4th millennium $\mathrm{BCE}$ ), the New Kingdom at Baqlia/Hermopolis (mid-2nd 


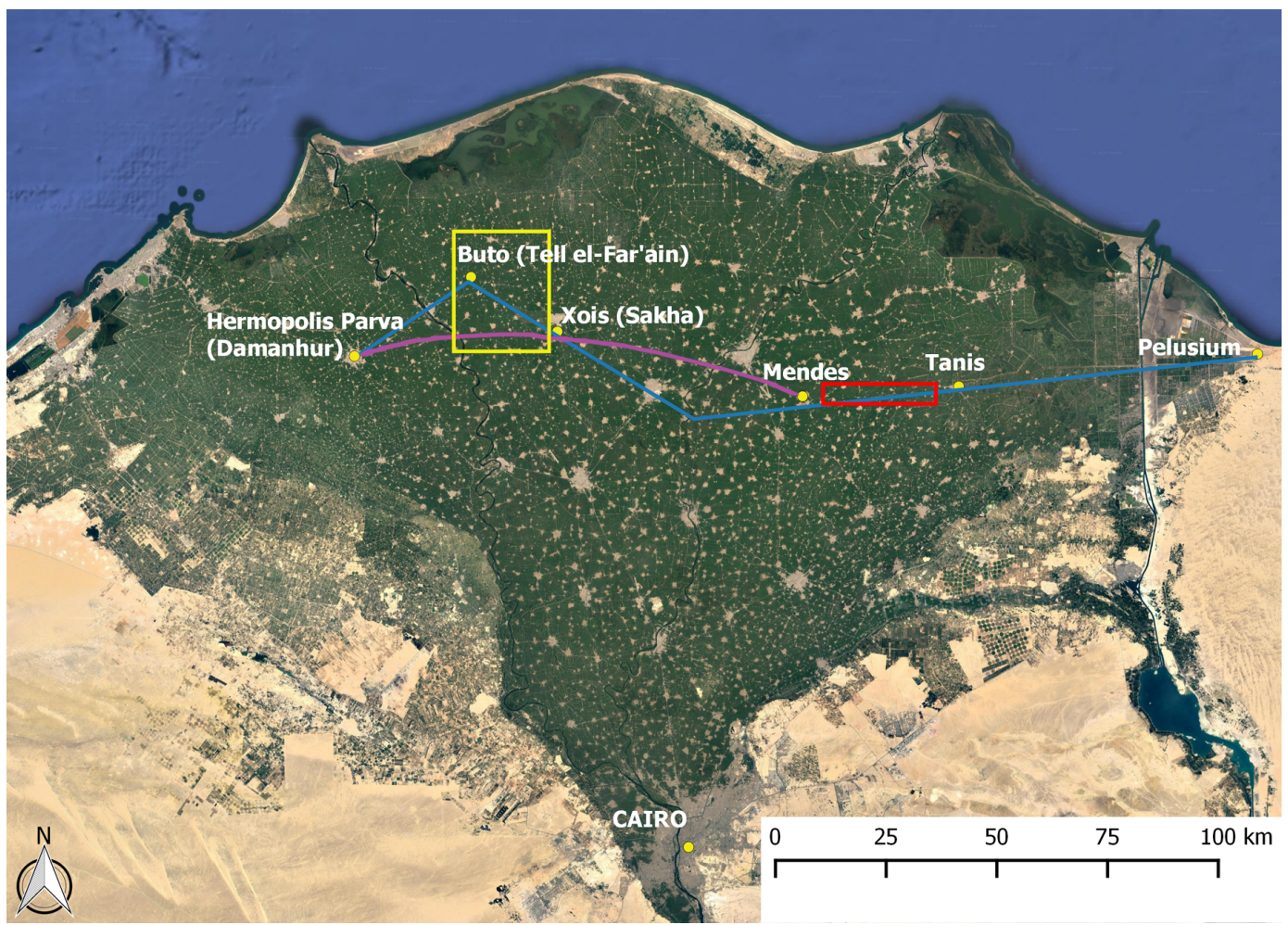

Figure 1. Nile delta, (C) Google Earth image. The blue line is the reconstruction of the Butic Canal by Talbert (2000), and the purple line is the reconstruction of the Butic Canal by Ball (1942). The rectangle outlined in red is the area enlarged in Fig. 2a-c, and the rectangle outlined in yellow is the area surveyed by the author.

millennium BCE), and the Third Intermediate Period at Tanis (11th century BCE), indicating a long tradition of trans-delta connections. This point is reinforced when we add a series of smaller, less well-known sites also located directly on this route (see Fig. 2c): Tell el-Dab ${ }^{c}$ a (EES 172, formerly known as Tell Qanan; Ball, 1942) was founded in the Predynastic Period, and Deir el-Hamra (EES 169) and El Tell el-Ahmar (EES 349) were founded in the Ptolemaic period. As few of these sites have been thoroughly investigated and published to date, in some cases the dating of their foundation may turn out to be earlier (dating information summarized on the Delta Survey web page: https://www.ees.ac.uk/delta-survey, last access: 3 August 2020). The eastern half thus seems to be older than the western but had fallen out of use by the later 1st century CE when Titus marched east. The western route used by Titus and his soldiers most likely made use of pre-existing canals which linked Nikopolis to the Canopic branch of the Nile and from that point on continued on a presumably new canal connecting the Canopic branch to the Mendesian branch. By the mid-2nd century CE, the eastern section, linking Mendes to Pelusium, had been reactivated or constructed anew, thus completing the trans-delta route and forming Ptolemy's Butic Canal. The date of construction is not known but probably falls between $70 \mathrm{CE}$ and the mid2nd century CE. This is a period of large-scale investment in Egyptian and Near-Eastern infrastructure (Sidebotham et al., 2000; Brun, 2018; Young, 2001), encompassing both the construction of public buildings, temples, canals, and roads and the foundation of a town (Antinoopolis), and it is suggested that the construction of the Butic Canal is to be placed in the context of such imperial building projects. A more detailed discussion of the chronology follows below in Sect. 5 .

\section{The route}

A series of European maps from the late 16th century (Mercator, 1578, 1584; Ortelius, 1584, 1592; see Silotti, 1998) show the Butic Canal as a straight line crossing through the delta. These maps, however, are not the results of observations based on actual visits to Egypt but attempts at implementing Ptolemy's description. In some respects, this generation of maps is a step back in the accuracy of representing topographic realities as compared to earlier medieval maps (Haguet, 2018). Standard modern editions of historic maps show somewhat different routes while still also following Ptolemy's description. The route shown in blue in Fig. 1 follows that of Talbert's Barrington Atlas of the Greek and Roman World (Talbert, 2000) and the route shown in purple that of Ball (1942). Again, the eastern section and the western section are best discussed separately. The course in the 

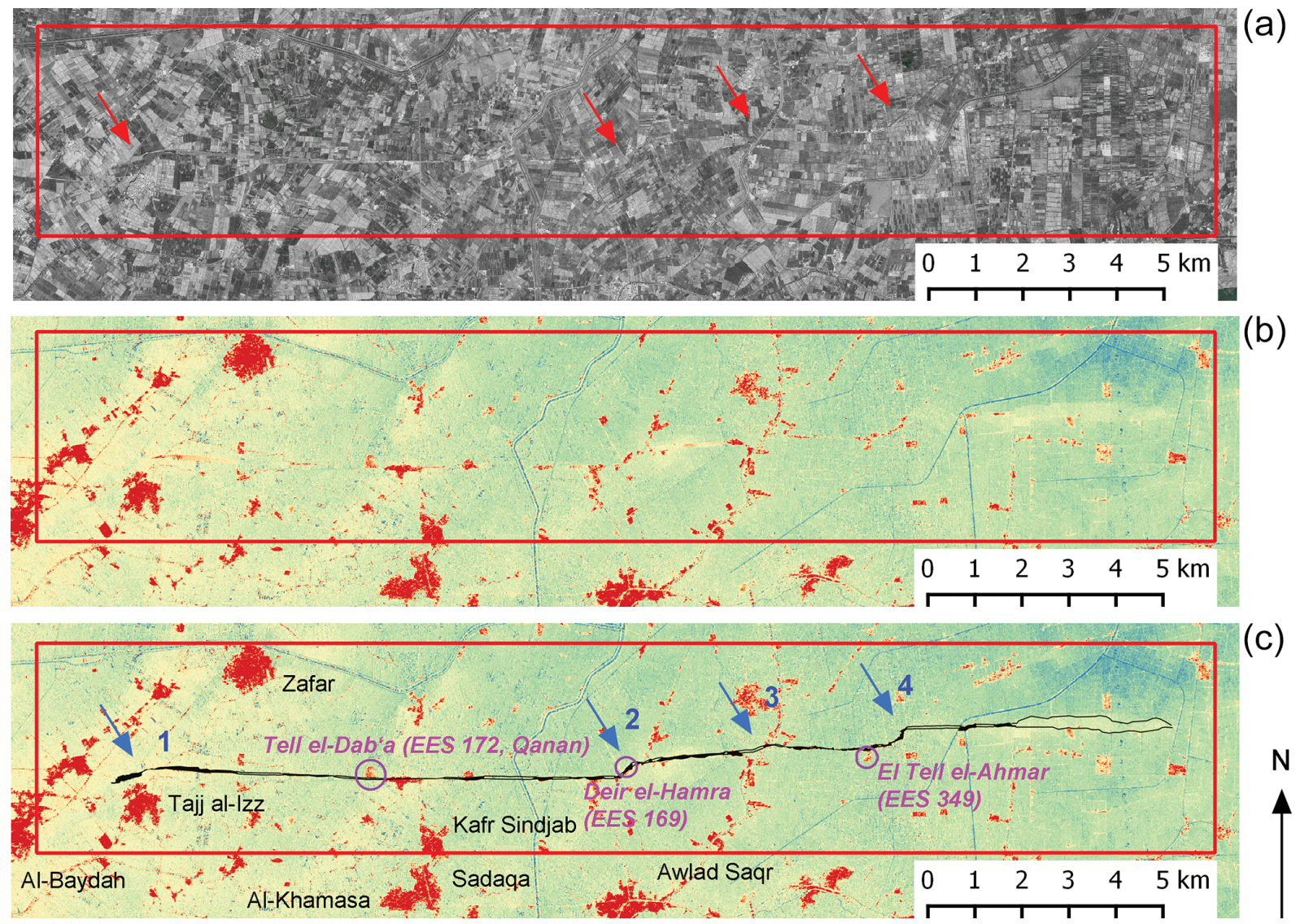

Figure 2. (a) Corona satellite image, 18 November 1968 (Corona Atlas of the Middle East, https://corona.cast.uark.edu, last access: 5 June 2020). (b) TanDEM-X digital elevation model of the area of investigation. TanDEM-X DEM courtesy of the German Aerospace Center (DLR). (c) TanDEM-X digital elevation model with the reconstructed course of the canal. TanDEM-X DEM courtesy of the German Aerospace Center (DLR). Names of ancient settlements shown in purple and modern names in black.

eastern part is based on an elevated feature which remains in parts still extant today. Compared to historic maps and older satellite imagery, such as the Corona image from 1968 (Fig. 2a), some details have been lost, but new data based on a digital elevation model (Fig. 2b) also provide new levels of detail in some areas. The information has been combined in Fig. 2c. This earthen linear feature, about $22 \mathrm{~km}$ long and of varying widths reaching a maximum of $140 \mathrm{~m}$, is widely assumed to represent the excavated material from the canal (Bietak, 1975). As the canal itself has not been detected, its relationship to the elevated feature is a matter of debate; it has been suggested that the watercourse originally ran north (Holz et al., 1980) or south (Bietak, 1975) of this feature. A position in the middle seems to be suggested by some Corona satellite imagery and fits the common pattern of canals with dikes on both sides.

For the route of the western half, however, there is to date no archeological evidence. Neither historic maps, satellite images, nor the new digital elevation model provide comparable data to those in the eastern delta. Historic maps show some short stretches of west-east features south of Buto, which also find themselves reflected in the digital elevation model, but we lack any information on dating and function. These segments are not paired by the elevated features as in the eastern delta. The reasons for the very different data, or better lack thereof, in the western delta remain unclear. At this point, it cannot be stated whether the difference is caused by varying formation processes of the canals, lengths of use, or natural or man-made transformation processes post-abandonment. With the increased use of remote sensing data, the interruption or disappearance of hydrological features in the delta landscape has already been observed for various natural features (Ginau et al., 2019).

Talbert (2000; similar to Wittke et al., 2007) shows the western segment of the canal emerging from the Canopic branch at the town of Hermopolis Parva/Mikra, modern Damanhur, and turning northeast in order to reach Buto (Fig. 1, blue line). This is based on the assumption that, due to its name, it must have passed the city of Buto. From Buto, the course then turns in a southeastern direction reaching the area of Sebennytos, which lies roughly on the same latitude as Mendes/Thmuis and Tanis. This requires the canal to flow 
from a lower-lying region to a higher region. Based on the modern surface, the canal would have flowed from a region of currently about $2 \mathrm{~m}$ a.s.l. (meters above sea level), past the region of Xois, modern Sakha, at around 5-6 ma.s.l., to a region of about 6-7 ma.s.l. at Sebennytos, modern Samannud. All in all, the difference in height would have been around $5 \mathrm{~m}$. We are missing, however, one fundamental piece of information: in which direction did the canal flow? The assumption west-east is suggested by the initial northeastern direction when branching off from the Canopic arm. The physical evidence in the eastern delta points in the same direction in that the canal displays a slightly northern shift moving east (Figs. 1 and 2, and discussion below). If the direction were reversed, that is from east to west, the canal would, following the blue route via Buto as shown in Fig. 1, be confronted with the same dilemma of having to flow uphill, albeit on a shorter stretch, namely from Buto to Hermopolis Parva/Damanhur. Overcoming differences in elevation in canals was technically possible in antiquity (Bockius, 2014). There is, however, a substantial effort involved, which begs the question of why such a route would be chosen. Was Roman Buto so significant it warranted such a detour? This seems unlikely, as Buto was neither a strategic, economic, or religious center of preeminent importance in this period. The region, however, was flourishing in Roman times. Two alternative scenarios emerge: firstly, the canal changes its direction of flow. In this scheme, in the western delta, the canal would flow from the west and from the east, in order to meet in Buto, where the water may have been redirected to northern distributaries. If this were the case, it would place Buto at the crucial junction and may explain naming the canal after this town. Secondly, a more southern course, minus the Buto detour, was chosen. If the town of Buto is no longer connected to the Butic Canal, how can the designation of Butic Canal then be explained? Butic does not necessarily refer to the town alone but is also applied to a larger region, the "land of Wadjet (Buto)", which we find outlined in the Satrap Stela of the late 4th century BCE (Schäfer, 2011). Redon (2018) has recently added further Roman examples for the descriptor Butikos applied to different topographic features or goods which are located or produced on a regional level. For example, Strabo mentions a Butic lake (XVII, 1, 18) which most likely refers to the northern lagoon, the later Lake Burullus. Butic linen is mentioned by Pliny (HN, XIX, II, 14) as a product of the district. In short, the canal may have been named Butic for crossing the region of Buto without actually passing the town, as was recently also suggested by Redon (2018). Such a southern route would avoid the above-discussed problems of flowing "uphill". Taking Ptolemy's description of the canal "parallel to the coast line" literally, a curved shape would seem the most likely, as was already proposed by Ball (1942; see Fig. 1, purple route). In this way, the canal could remain on the same elevation while flowing west-east. For the eastern delta, new data are available in the form of a digital elevation model (DEM) which provides a greater level of detail (Fig. 2b and c). The DEM, based on the German satellite pair TanDEM-X, was acquired in cooperation with the German Aerospace Center in order to investigate the landscape in the survey area (Ginau et al., 2019). Due to the high resolution of the elevation information, it has been possible to use these data very successfully for the region north of Buto in order to reconstruct ancient watercourses based on the traces of elevated levees. No features, however, were detected which suggest themselves as being part of a west-east delta transversal route. In the eastern delta, the elevated linear feature appears clearly, and some new details emerge, which will be discussed in the following.

On the segment between Mendes/Thmuis and Tanis (Fig. 2c), four sharp bends, or "steps", are detectable. They are designated, from west to east, steps 1-4. In such a step, the canal turns sharply in a northeastern direction and, after a length of between 480 and $843 \mathrm{~m}$, turns right again in order to continue due east in a linear fashion. The distance between these steps is between 2.3 and $10.5 \mathrm{~km}$. In this way, the canal is incrementally shifting slightly north: over the distance of $22 \mathrm{~km}$, about $1 \mathrm{~km}$. In steps 1,2 , and possibly 3 , the steps coincide with an intersection with an elevated feature, most likely an ancient branch. These steps possibly served to support the crossing of branches, feeding them in and out of the canal. In Bietak's reconstruction (1975), there are small branches crossing the canal in the area of steps 1 and 3. Between steps 1 and 2, east of Tell el-Dab ${ }^{c}$ a (EES 172), there is also an elevated feature crossing the canal, but there is no evidence for a step. This was possibly the levee of an old waterway which was no longer active. A similar stepped feature, albeit on a much smaller scale, was archeologically investigated in the middle of the Fossa Corbulonis, a 1st century CE Roman canal in the Netherlands (de Kort and RazcynskiHenk, 2014). This canal, which on average has a width of $12-15 \mathrm{~m}$, narrows here to $4 \mathrm{~m}$. The feature was interpreted as a portage, an area where the ship had to be taken out of the water and dragged over land, before being placed back in the canal. In the case of the Fossa Corbulonis, it was a measure to balance different levels of water. This does, upon first impression, not seem to be the case in the Butic Canal, but the definite function remains unclear. As the settlements are directly attached to the canal, these stepped features possibly served the purpose of redirecting the canal closer to some settlements. In between the steps, the canal runs along a mostly linear course. Notably, between steps 1 and 2, there is a slight southward shift of around $286 \mathrm{~m}$ between the top of step 1 and the base of step 2 . With step 2 , the course returns to its northward direction. This stretch of the canal provides the first detailed evidence of a Roman period artificial watercourse in the delta. Targeted archeological investigations and comparisons with other Roman period canals could supply crucial further understanding. 


\section{The function(s) of the canal}

Apart from Josephus' description of the movement of troops on the "Titus Canal", the sources remain silent on the uses of the trans-delta route. The military purpose of the Titus Canal has been projected onto the later Butic Canal, comparing its construction to that of "Hitler's and Mussolini's highways" (Carrez-Maratray, 1999). Taking this analogy as a cue, it should be noted that current analysis of the program of the construction of highways by National Socialist Germany discusses them as tools of propaganda, embodying numerous ideas far more varied than those purely focused on strategic military deployment. A recent discussion shows how 1930s Autobahnen were conceived as a tool of healing a perceived rupture between landscape and technology. Autobahnen were deeply embedded in evolving concepts of landscape and in turn had a massive effect on the landscape (Zeller, 2007). Josephus' account itself raises questions for the strategic value of this route. Titus' journey was undertaken in three parts of distinctly different lengths: part 1, by ship from Nikopolis to Thmuis and continuing on land from Thmuis to Tanis, covered almost $200 \mathrm{~km}$ and was by far the longest; part 2, on land from Tanis to Herakleopolis Parva (Tell Belim), was about $28 \mathrm{~km}$ long; and part 3, from Herakleopolis Parva to Pelusium, was about $37 \mathrm{~km}$ long. Josephus writes that after arriving at Pelusium, the soldiers rested for $2 \mathrm{~d}$ (BI IV, 11, 5). Evidently reaching Jerusalem as fast as possible was not the main concern. It has been suggested that the journey by Titus was undertaken to test the strategic efficiency of the canal (Carrez-Maratray, 1999). The basic question remains: why bother creating such a watercourse parallel to the Mediterranean, in particular when the point of departure lay on the coast? One reason may have been the seasonality of sea travel, which due to weather conditions in the Mediterranean all but ceased in the winter. Between October, at the latest November, and March or April, large ships avoided traveling in the Mediterranean Sea. Additionally, entering and leaving Nile mouths presented challenges which made circumventing them attractive (Cooper, 2014). During this period, the transportation of goods switched to land routes or had to wait until spring. Titus' journey did indeed take place in winter. While the emperor Vespasian stayed in Alexandria and postponed his return to Rome until winter was over, Titus and his troops were sent off in the direction of Judea, with the siege of Jerusalem taking place in spring shortly before Passover (Jos. BI, IV, 11, 5; V, 3, 1; Schäfer, 2003). Thus, the canal created the strategic advantage of allowing transport by ship also in the winter. The Butic Canal itself, however, fell into the category of seasonal canals which were not operational year-round. Once the Nile was very low, they were dammed off and the dams were opened only after the peak of the flood. Such canals were active from September to the end of December/early January (Cooper, 2014). While the data on this are late antique, medieval, and modern, it seems likely that the same system was in place in Roman times. The period of activity falls into the period with no or only very dangerous sea travel, reducing this period to January to March and thus underscoring the value of an alternative provided by an artificial waterway. While the ancient sources remain silent on the Butic Canal's purpose, in other cases they supply an intriguing variety of reasons for the construction of waterways. The Fossa Corbulonis, connecting the Rhine and the Meuse in the Netherlands and being ca. $30 \mathrm{~km}$ in length, was built in the mid-1st century CE and has only recently been identified archeologically (de Kort and Raczinsky-Henk, 2014). According to Tacitus, it was built to keep troops busy and to provide a route to circumvent the dangers of the North Sea (Ann. XI, 18-20), while Cassius Dio (Hist Rom LXI 30, 4-6) provides another reason, namely that it could serve as a water management system. Seemingly inconsistent, these different purposes may reflect a blend of concepts, original functions, and eventual uses. In canals with long and complex biographies, primary purposes and later functions may vary fundamentally (Salomon et al., 2014). The Red Sea Canal, verifiably completed in the Persian period, certainly served the political purpose of binding Egypt, now a Persian province, closer to the Persian heartland. After the Persian domination over Egypt ended, the canal was rebuilt in the Ptolemaic period and later again in the Roman period with different functions, such as providing commercial links to the Red Sea, Arabia, and southern India, as well as a strategic role in Trajan's Parthian wars (Sijpesteijn, 1963; Reddé, 1986; Cooper, 2009). The canal also generated settlement development, with the foundation of a Ptolemaic harbor settlement adjoining the canal, and an opportunity to set up stelae extolling royal accomplishments along its path. While only Persian and Ptolemaic examples of such stelae survive from the Red Sea Canal, the erection of Roman stelae is very likely. If Titus had 14 stelae set up for the, in comparison, minor Agathos Daimon canal, discussed above in Sect. 2, the Roman Red Sea Canal and the Butic Canal provided greater opportunities for imperial self-presentations. That a canal was actually only re-excavated or repaired and not built from scratch is notably mentioned in Titus' stelae but not in the Persian or Ptolemaic stelae along the Red Sea Canal. Young (2001) considers the construction of the Red Sea Canal less an act "of economic policy and more as an act of euergetism". Roman roads - and canals by inference - are, as Kolb summed it up recently, "instrument and symbol of Roman rule" (Kolb, 2019). Imperial connectivity, in particular in the eastern part of the Roman empire, was greatly enhanced in the 2nd century CE. Such infrastructure measures also served travelers beyond the borders of the empire, as evidenced in Lucian's description of a journey of a young man in $170 \mathrm{CE}$ sailing from Alexandria to Clysma thanks to the Red Sea Canal and continuing to India (Young, 2001). The Butic Canal was most likely also used for strategic purposes and provided a seasonal alternative to sea travel. Troops stationed in Egypt were moved to assist in eastern conflicts even prior to the Jewish 
uprising in $70 \mathrm{CE}$, for which the Titus Canal may have been built. Starting with an Armenian war of succession against Nero in 58-63, a pattern emerges during the 1st and 2nd centuries $\mathrm{CE}$ in which entire Egyptian legions or parts of them were involved in numerous conflicts in the east. The two main theaters of conflict were the wars with the Parthians and the Jewish uprisings in Judea. Movements of troops went in both directions, with the contingents leaving Nikopolis and eventually returning; occasionally other troops were shifted around (Mor, 2016). The Egyptian III legion, Cyrenaica, participated in Trajan's Parthian wars (Gilliam, 1966), and a vexillation of this legion was stationed in Jerusalem in 116 (Cotton, 2000, 353). For the suppression of the Jewish revolts in Egypt in 115-117 CE, troops were moved there to replace losses of soldiers (Gilliam, 1966). In the 130s CE, during the Bar Kokhba revolt, it is quite likely that the Egyptian XXII legion, Deiotoriana, was transferred to Judea (Millar, 1993; Eck, 1999). In this period, there was massive investment in road construction in the eastern provinces, particularly in Judea, which provided a military corridor between Egypt, Arabia, and Syria (Schäfer, 1990). However, the Judean road constructions under Hadrian took place in the years 120 and 129/30 CE prior to the Bar Kokhba revolt (Isaac, 1990). The building activities are thus not a strategic reaction to the unrest but are likely linked to the emperor's journey to Judea. Hadrian's visit to Egypt in 130-131 CE took him from Pelusium to Alexandria (Vita Hadriani, 14, 4; Cassius Dio, Hist Rom LXIX, 11.1; Sijpesteijn, 1969), but no information is provided on how this trip was undertaken (Halfmann, 1986; Birley, 2003). The Butic Canal possibly formed part of an imperial construction program linked to Hadrian's journey. It has been argued that Hadrian's visit to Egypt in 130 was his second, preceded by a visit in 117 shortly after his accession (Capponi, 2010). As in the trip of 130, Hadrian's entry to Egypt is suggested to have been from the east and continuing to Alexandria. This journey possibly fostered the plans to build an imperial canal, which may have been inaugurated on his second journey. Hadrian's visit(s) to Egypt were accompanied by the restoration of buildings and temples which formed part of an "imperial image campaign" (Capponi, 2010). The canal must have also had a major effect on the water system of the delta (Ball, 1942; Bietak, 1975; Blouin, 2008). The crossing branches of the Nile fed the canal, reducing the flow of water in these branches. It could, thus, have served as a sort of valve to regulate and distribute the Nile flood and may have been harnessed for irrigation purposes. The earthen dikes of the canal built across the delta plain would also have served to regulate the flood, as suggested by Bietak (1975). During Trajan's and Hadrian's reigns, low Nile floods are attested (Sijpesteijn, 1969; Pfeiffer, 2010) which may have been the reason for improvements to the canal-system undertaken during their reigns. The $\mathrm{Bu}-$ tic Canal was possibly part of this scheme. Just as the date of the canal's opening remains unclear, so does the date of its demise. The very substantial elevated linear feature in the eastern half is probably the result of continued dredging over a longer time period, with the deposited earth thus creating a higher levee. Much of this may, however, have already accumulated during the canal's Pharaonic and Ptolemaic existence prior to the completion of the Roman Butic Canal. The lack of any trace of such a feature in the western section may reflect that part's shorter life use. By the early 4th century $\mathrm{CE}$, the Butic Canal no longer seems to have been in use. The detailed travel log of Theophanes (Matthews, 2006), who in $320 \mathrm{CE}$ traveled from Hermopolis in Middle Egypt to Antioch in Syria, crossed the delta from Thmuis to Tanis, and continued to Herakleopolis and to Pelusium on exactly the route covered by the Butic Canal. He did not, however, go by ship but on land, most likely in a horse drawn carriage. As he traveled in mid-March, this may have been due to seasonal reasons, when the low Nile made travel on canals all but impossible. The road traveled was likely on the dike of the Butic Canal. These elevated features provided the traditional placement for roads secure from the floods. In the eastern segment, from Thmuis to Pelusium, the route of a road crossing the delta shown on the tabula Peutingeriana (Talbert, 2010) concurs with that of the Butic Canal. The tabula Peutingeriana is a medieval copy of a map compiled in the late Roman period from mixed sources, some of which date to the early Roman period (Arnaud, 1990). It is very likely that this road was erected on the dike of the Butic Canal. On the stretch from Tanis to Pelusium, the remains of the $\mathrm{Bu}$ tic Canal may be depicted on the tabula Peutingeriana, with the road shown running parallel to a west-east watercourse (Redon, 2018). The full length of the Butic Canal most likely was not in existence very long. In contrast to other imperial prestige projects, canals required intense yearly maintenance lest they fall into disuse. The canal possibly fell apart into segments again, with an eastern part remaining in function and providing a local transportation route.

\section{Conclusions}

The Butic Canal was most likely created by reactivating existing canals: a Flavian section in the western delta and a possibly Pharaonic route in the eastern delta. Its route did not pass by the town of Buto but ran further south, crossing the region of Buto. Based on a digital elevation model, new features are clearly discernible in the eastern section of the canal. Four sharp bends, or steps, shift its course slightly north. These features possibly served to feed crossing watercourses in and out of the canal. The greatest artificial watercourse of Egypt was completed sometime between $70 \mathrm{CE}$ and the mid-2nd century CE. It may have been built in connection with Hadrian's visit to Egypt and thus be considered less a strategic necessity than a representation of imperial rule. When traveling east from Alexandria by ship, the canal did provide a seasonal alternative to the Mediterranean route, which was to be avoided in the winter. It must have had a sub- 
stantial impact on the waterscape of the delta and may have been an attempt at creating a new water management system. Whether this was entirely beneficial remains unclear, but the yearly maintenance required possibly outweighed the benefits and led to the abandonment of this cross-delta route. The canal's last traces may be found on the tabula Peutingeriana on which in the eastern delta a road is shown running parallel to a watercourse, quite likely on the dike of the Butic Canal. This study demonstrates the usefulness of new data, such as the TanDEM-X digital elevation model, used in combination with newly available data, such as the Corona satellite imagery, for the fields of archeology, landscape archeology, and geoarcheology of the Nile Delta.

Data availability. The TanDEM-X digital elevation model is used with the permission of the German Aerospace Center (DLR) and is based on the data requested via the proposal (DEM_HYDR1426) by Andreas Ginau, Robert Schiestl, Jürgen Wunderlich, Eva LangeAthinodorou, and Tobias Ullmann. The TanDEM-X data are used within the framework of the agreement with the German Aerospace Center (DLR) and are not freely accessible.

Competing interests. The author declares that there is no conflict of interest.

Special issue statement. This article is part of the special issue "Geoarchaeology of the Nile Delta". It is a result of the workshop "Geoarchaeology of the Nile Delta: Current Research and Future Prospects”, Würzburg, Germany, 29-30 November 2019.

Acknowledgements. I am grateful for the assistance of Andrea Squitieri in preparing the maps and for Henry HeitmannGordon and Janice Schiestl for helpful comments and for correcting my English. I am also grateful to the two anonymous reviewers for their valuable comments and suggestions.

Review statement. This paper was edited by Tobias Ullmann and reviewed by two anonymous referees, one of whom requested to be thanked anonymously in the Acknowledgements.

\section{References}

Arnaud, P.: L'origine, la date de rédaction et la diffusion de l'archétype de la Table de Peutinger, Bulletin de la Société Nationale des Antiquaires de France, 1988, 302-321, https://doi.org/10.3406/bsnaf.1990.9424, 1990 (in French).

Ball, J.: Egypt in the Classical Geographers, Survey of Egypt, Government Press, Cairo, Egypt, 1942.

Bietak, M.: Tell el-Dab ${ }^{c}$ a II. Der Fundort im Rahmen einer archäologisch-geographischen Untersuchung über das ägyptische Ostdelta, Untersuchungen der Zweigstelle Kairo des Österre- ichischen Archäologischen Instituts 1, Denkschriften der Gesamtakademie der Österreichischen Akademie der Wissenschaften 4 , Austrian Academy of Sciences, Vienna, Austria, 1975 (in German).

Birley, A. R.: Hadrian's Travels, in: The Representation and Perception of Roman Imperial Power. Proceedings of the Third Workshop of the International Network Impact of Empire (Roman Empire, c. 200 B.C.-A.D. 476), Netherlands Institue in Rome, March 20-23, 2002, edited by: de Blois, L., Erdkamp, P., Hekster, O., de Kleijn, G., and Mols, S., J. C. Gieben, Amsterdam, 425-438, 2003.

Blouin, K.: De Mendès à Thmouis: hydrographie mobile, société mobile?, in: L'eau comme patrimoine--de la Méditerranée à l'Amérique du Nord, edited by: Hermon, E., Presses de l'Université Laval, Québec, Canada, 107-128, 2008 (in French).

Blouin, K.: Triangular Landscapes. Environment, Society, and the State in the Nile Delta under Roman Rule, Oxford University Press, Oxford, United Kingdom, https://doi.org/10.1093/acprof:oso/9780199688722.001.0001, 2014.

Bockius, R.: Künstliche Schifffahrtswege. Wasserbau und hydrotechnische Einrichtungen im Altertum, in: Großbaustelle 793 Das Kanalprojekt Karls des Großen zwischen Rhein und Donau. Mosaiksteine. Forschungen am RGZM 11, edited by: Ettel, P., Daim, F., Berg-Hobohm, S., Werther, L., and Zielhofer, C., Verlag des Röm.-German. Zentralmuseums, Mainz, Germany, 8794, 2014 (in German).

Bonneau, D.: Le régime administratif de l'eau du Nil dans l'Égypte grecque, romaine et byzantine, Probleme der Ägyptologie 8, Brill, Leiden, The Netherlands, 1993 (in French).

Brun, J.-P.: Chronology of the Forts of the Routes to Myos Hormos and Berenike during the Graeco-Roman Period, in: The Eastern Desert of Egypt during the Greco-Roman Period: Archaeological Reports, Paris: Collège de France, https://doi.org/10.4000/books.cdf.5239, 2018.

Capponi, L.: Hadrian in Jerusalem and Alexandria in 117, Athenaeum, 98, 489-501, 2010.

Carrez-Maratray, J.-Y.: Péluse et l'angle oriental du Delta égyptien aux époques grecque, romaine et byzantine ,Bibliothèque d'étude 124, Institut Français d'Archéologie Orientale, Cairo, Egypt, 403-404, 1999 (in French).

Cooper, J. P.: Egypt's Nile-Red Sea Canals: Chronology, Location, Seasonality and Function, in: Connected Hinterlands. Proceedings of the Red Sea Project IV Held at the University of Southampton September 2008, Society for Arabian Studies Monographs No. 8, BAR International Series 2052, edited by: Blue, L., Cooper, J. P., Thomas, R., and Whitewright, J., Archaeopress, Oxford, United Kingdom, 195-210, 2009.

Cooper, J.P.: The Medieval Nile: Route, Navigation, and Landscape in Islamic Egypt, American University in Cairo Press, Cairo, Egypt, 2014.

Cotton, H.: The Legio VI Ferrata, in: Les légions de Rome sous le Haut-Empire I, edited by: Le Bohec, Y., de Boccard, Lyon, France, 351-357, 2000.

De Kort, J.-W. and Raczynski-Henk, Y.: The Fossa Corbulonis between the Rhine and Meuse estuaries in the Western Netherlands, in: Roman canal studies, Water History 6/1, edited by: Salomon, F., Purdue, L., Goiran, J.-P., and Berger, J.-F., Springer, Berlin, 
Heidelberg, Germany, 51-71, https://doi.org/10.1007/s12685014-0097-3, 2014.

Gilliam, J. F.: An Egyptian Cohort in A.D. 117, in: Bonner Historia Augusta-Colloquium 1964/1965, Bonn, 91-97, 1966.

Eck, W.: The Bar-Kokhba Revolt: The Roman Point of View, Journal of Roman Studies, 89, 76-89, 1999.

Ginau, A., Schiestl, R., and Wunderlich, J.: Integrative geoarchaeological research on settlement patterns in the dynamic landscape of the northwestern Nile delta, QI, 511, 51-67, https://doi.org/10.1016/j.quaint.2018.04.047, 2019.

Grewe, K.: Tunnels and Canals, in: The Oxford Handbook of Engineering and Technology in the Classical World, edited by: Oleson, J. P., Oxford University Press, Oxford, United Kingdom, 319-336, https://doi.org/10.1093/oxfordhb/9780199734856.013.0013, 2009.

Haguet, L.: Egypt and Maps, Or: What Early Modern Maps Are (Not) Telling Us about the History of Egyptology in Europe, in: Mapping Ancient Identities. Methodisch - kritische Reflexionen zu Kartierungspraktiken, Berlin Studies of the Ancient World 55, edited by: Grunwald, S., Hofmann, K. P., Werning, D. A., and Wiedemann, F., Edition Topoi, Berlin, Germany, 91-113, https://doi.org/10.17171/3-55, 2018.

Hairy, I. and Sennoune, O.: Le canal d'Alexandrie: la course au Nil, in: Du Nil à Alexandrie: histoires d'eaux, edited by: Hairy, I., Céntre d'Études Alexandrines, De Boccard, Alexandrie, 140161, 2011 (in French).

Halfmann, H.: Itinera Principum. Geschichte und Typologie der Kaiserreisen im Römischen Reich, F. Steiner Verlag, Stuttgart, Germany, 1986 (in German).

Holz, R. K., Stieglitz, D., Hansen, D. P., and Ochsenschlager, E.: Mendes I, American Research Center in Egypt, Cairo, Egypt, 1980.

Isaac, B.: The Limits of Empire. The Roman Army in the East, Clarendon Press, Oxford, United Kingdom, 1990.

Jördens, A.: Statthalterliche Verwaltung in der römischen Kaiserzeit, Studien zum praefectus Aegypti, Historia Einzelschriften 175, Steiner, Stuttgart, Germany, 2009 (in German).

Kolb, A.: Via ducta - Roman Road Building: An Introduction to Its Significance, the Sources and the State of Research, in: Roman Roads. New Evidence - New Perspectives, edited by: Kolb, A., de Gruyter, Berlin, Boston, 3-21, https://doi.org/10.1515/9783110638332-002, 2019.

Matthews, J.: The journey of Theophanes. Travel, Business, and Daily Life in the Roman East, Yale University Press, New Haven, USA, 2006.

Millar, F.: The Roman Near East, 31 BC-AD 337, Harvard University Press, Cambridge, MA, USA, 1993.

Mor, M.: The Second Jewish Revolt. The Bar Kokhba War, 132-136 CE, The Brill Reference Library of Judaism 50, Brill, Leiden, The Netherlands, 2016.

Pfeiffer, S.: Der römische Kaiser und das Land am Nil. Kaiserverehrung und Kaiserkult in Alexandria und Ägypten von Augustus bis Caracalla (30 v.Chr.-217 n.Chr.), Historia Einzelschrift 212, Steiner, Wiesbaden, Germany, 2010 (in German).
Reddé, M.: Mare nostrum. Les infrastructures, le dispositive et l'histoire de la marine militaire sous l'Empire romain, École française de Rome, Rome, Italy, 1986 (in French).

Redon, B.: Les circulations transversales dans le Delta égyptien - entre adaptation au paysage et nécessités pratiques, in: Landscape Archaeology, Egypt and the Mediterranean World, Proceedings of the Cairo Conference, Bibliothèque d'étude 169, edited by: Tristant, Y. and Ghilardi, M., Institut Français d'Archéologie Orientale, Cairo, Egypt, 151-172, 2018 (in French).

Salomon, F., Purdue, L., Goiran, J.-P., and Berger, J.-F.: Introduction to the special issue: Roman canal studies - Main research aims, Water History, Springer, Berlin, Germany, 1-9, 2014.

Schäfer, D.: Makedonische Pharaonen und hieroglyphische Stelen. Historische Untersuchungen zur Satrapenstele und verwandten Denkmälern, Studia Hellenistica 50, Peeters, Leuven, Belgium, 2011 (in German).

Schäfer, P.: Hadrian's policy in Judaea and the Bar Kokhba revolt: a reassessment, in A Tribute to Geza Vermes. Essays on Jewish and Christian Literature and History, Journal for the Study of the Old Testament Supplement Series 100, edited by: Davies, P. R. and White, R. T., JSOT Press, Sheffield, United Kingdom, 281-303, 1990.

Schäfer, P.: The History of the Jews in the Greco-Roman world, Routledge, London, United Kingdom, 2003.

Scheuble, S.: Inschriften aus Schedia, Chiron, 39, 463-503, 2009 (in German).

Schiestl, R.: Field Boundaries and Ancient Settlement Sites: Observations from the Regional Survey around Buto, Western Delta, in: Mitteilungen des Deutschen Archäologischen Instituts, Abteilung Kairo, 68, 175-190, 2012.

Sidebotham, S. E., Zitterkopf, R. E., and Helms, C. C., Survey of the Via Hadriana: The 1998 Season, J. Am. Res. Center Egypt, 37, 115-126, 2000.

Sijpesteijn, P. J.: Der ПОТАMO $\Sigma$ TPAIANO $\Sigma$, Aegyptus, 43, No. 1/2, 70-83, 1963.

Sijpesteijn, P. J.: A New Document concerning Hadrian's Visit to Egypt, Historia, 18, 109-118, 1969.

Silotti, A.: The Discovery of Ancient Egypt, Edizione White Star, Vercelli, Italy, 1998.

Stückelberger, A. and Graßhoff, G. (Eds.): Klaudios Ptolemaios. Handbuch der Geographie: griechisch-deutsch; Einleitung, Text und Übersetzung, Index/1: Einleitung und Buch 1-4, Schwabe, Basel, Switzerland, 2006 (in German).

Talbert, R. J. A.: Barrington Atlas of the Greek and Roman World, Princeton University Press, Princeton, USA, 2000.

Talbert, R. J. A.: Rome's World: The Peutinger Map Reconsidered, Cambridge University Press, Cambridge, United Kingdom, 2010.

Wikander, C.: Canals, in: Handbook of Ancient Water Technology, Technology and Change in History, Vol. 2, edited by: Wikander, Ö., Brill, Leiden, The Netherlands, 321-330, 2000.

Wittke, A.-M., Olshausen, E., Szydlak, R.: Historischer Atlas der antiken Welt, Der Neue Pauly, Supplemente, J. B. Metzler Verlag, Stuttgart, Germany, 2007.

Young, G.: Rome's Eastern Trade. International commerce and imperial policy, 31 BC-AD 305, Routledge, London, United Kingdom, 2001. 
Yoyotte, J.: Tells oubliés de la region de Sân, in: Cahiers de Tanis I, Éditions Recherche sur les Civilisations, Paris, 107-112, 1987 (in French).

Zeller, T.: Driving Germany. The landscape of the German Autobahn, 1930-1970, Studies in German History 5, Berghahn Books, New York, USA, 2007.

Zimmermann, M.: Der Kaiser als Nil, in: PropagandaSelbstdarstellung - Repräsentation im römischen Kaiserreiche des 1. Jhs. n. Chr., Historia Einzelschriften 164, edited by: Weber G., and Zimmermann, M., Steiner, Stuttgart, Germany, 317-348, 2003 (in German).
Zivie-Coche, C.: Statues et autobiographies de dignitaires, Tanis à l'époque Ptolémaique, Tanis, Travaux récents sur le Tell San El-Hagar, mission française des fouilles de Tanis 3, Éd. Noesis, Paris, France, 2004 (in French). 